\title{
THE VALUE OF UTILIZING EXISTING SHADE IN THE GROWING OF VANILLA
}

\author{
$\mathrm{By}$ \\ Ernesto Hernindez Medina \\ Formerly Collaborating Agronomist (1) \\ Puerto Rico Experiment Station \\ U. S. Department of Agriculture \\ Mayagüez, P. R.
}

Vanilla grew more rapidly on underbrushed land with existing shade than on cleared land with replanted shade.

The customary practice in the early plantings of vanilla in Puerto Rico was to clear the land and plant trees, such as the dwarf bucare (Erythrina berteroana Urban), for shade and support. This resulted in a delay of 1 or 2 years before actual planting of the vanilla could be made. From observations and trial it was found that many varied trees could be used as supports for vanilla and that usually the trees already on the lant and producing shade were entirely adequate. Under this method planting can be started immediately, and by utilizing existing facilities, costs can be much reduced.

In 193\%, a parcel of land on the grounds of the Puerto Rico Experiment Station at Mayaguiez was prepared by clearing all trees and underbrush from one-half of the area and only the underbrush from the remainder. Both portions were planted with support stakes of dwarf bucare. On October 25, 1939, when the bucare in the completely cleared portion had grown sufficiently to afford proper shade, 100 8-node ranilla cuttings of uniform size and vigor were planted in both areas.

Root formation was superior on vines under existing shade.

A record of the number of roots formed on the cuttings in each treatment was made every second month for 1 year, as shown in table 1 .

(1) In cooperation with the Government of Puerto Rico. 
Table 1. Cumulative root formation found on vanilla cuttings at bimonthly intervals after planting at the base of support trees on cleared land and on underbrushed land on October 25, 1939.

\begin{tabular}{c|c|c|c|c|c|c}
\hline & \multicolumn{5}{|c}{ Roots formed } \\
\cline { 2 - 6 } Treatment & Dec. 26 & Feb. 23 & Apr. 26 & June 26 & Aug. 26 & Oct. 26 \\
\hline $\begin{array}{c}\text { Planted on cleared } \\
\text { land - }\end{array}$ & 247 & $222(1)$ & $154(1)$ & $135(1)$ & $127(1)$ & $121(1)$ \\
$\begin{array}{c}\text { Planted on land } \\
\text { with } \\
\text { existing shade. }\end{array}$ & 409 & 419 & 426 & 433 & 436 & $426(1)$ \\
\hline
\end{tabular}

(1) Decrease in number of roots was due to decay of some roots previously formed.

It is evident that the vines planted under existing shade produced the greater number of roots throughout the experiment. The root formation of the vines planted under existing shade, was over thrice as great as that of the vines planted on cleared land, and the rotting of newly formed roots was considerably delayed. This decay can probably be accounted for by the quality of the shade provided by the existing trees as compared to the limited shade provided in the cleared area by the bucare support trees.

Amount of seed-piece rotting was considerably less on vines under existing shade.

The information gathered regarding seed-piece deterioration is summarized in table 2.

Table 2. Extent of seed-piece rotting.

\begin{tabular}{c|c|c|c|c|c|c}
\hline & \multicolumn{5}{|c}{ Decayed seed-piece internodes } \\
\cline { 2 - 7 } Treatment & Dec. 26 & Feb. 26 & Apr. 26 & June 26 & Aug. 26 & Oct. 26 \\
\hline $\begin{array}{c}\text { Planted on } \\
\text { cleared land }\end{array}$ & 5.0 & 13.7 & 38.0 & 53.4 & 59.1 & 61.0 \\
$\begin{array}{c}\text { Planted on } \\
\text { land with }\end{array}$ & 1.6 & 1.6 & 2.1 & 3.3 & 4.4 & 6.8 \\
\hline \begin{tabular}{c} 
existing shade \\
\hline
\end{tabular}
\end{tabular}


As can be observed for table 2, of the vanilla cuttings planted, 61.0 percent developed stem rot on cleared land, while under existing shade only 6.8 percent were so affected. The greatest amount of stem rotting occurred during the dry season; at this time of the year the bucare supports shed their leaves and consequently many of the vanilla cuttings were exposed to direct sunlight, which apparently favored stem rotting.

A mount of vegetative growth was superior in vines under existing shade.

Data on the amount of vegetative growth are shown in table 3.

Table 3. Vegetative growth of vanilla vines planted on cleared land and on land with existing shade, October 25, 1939.

\begin{tabular}{l|c|c|c|c|c|c}
\hline & \multicolumn{5}{|c}{ Avcrage stem growth per cutting } \\
\cline { 2 - 6 } Treatment & Dec. 26 & Feb. 26 & Apr. 26 & June 26 & Aug. 26 & Oct. 26 \\
\hline $\begin{array}{c}\text { Planted on } \\
\text { cleared land }\end{array}$ & 2.76 & 7.32 & 10.96 & 16.84 & 26.26 & 21.41 \\
$\begin{array}{c}\text { Planted on } \\
\text { land with } \\
\text { existing shade }\end{array}$ & 3.55 & 4.96 & 7.35 & 16.77 & 32.51 & 53.42 \\
\hline
\end{tabular}

During the early part of the experiment, the amount of vegetative growth per plant on vines planted on cleared land was somewhat greater than that on the vines under existing shade. Vegetative growth per plant by June, 8 months after planting, was about equal for both treatments. From August to October, which period composes part of the rainy season in this district, the plants grown under existing shade greatly surpassed the other planting. It is evident that the amount of vegetative growth per plant was over twice as great as that of the vines grown on cleared land.

The total amount of vegetative growth of the cuttings together with the root germination and rotting of the seed pieces per treatment is shown graphically in figure 1 . 


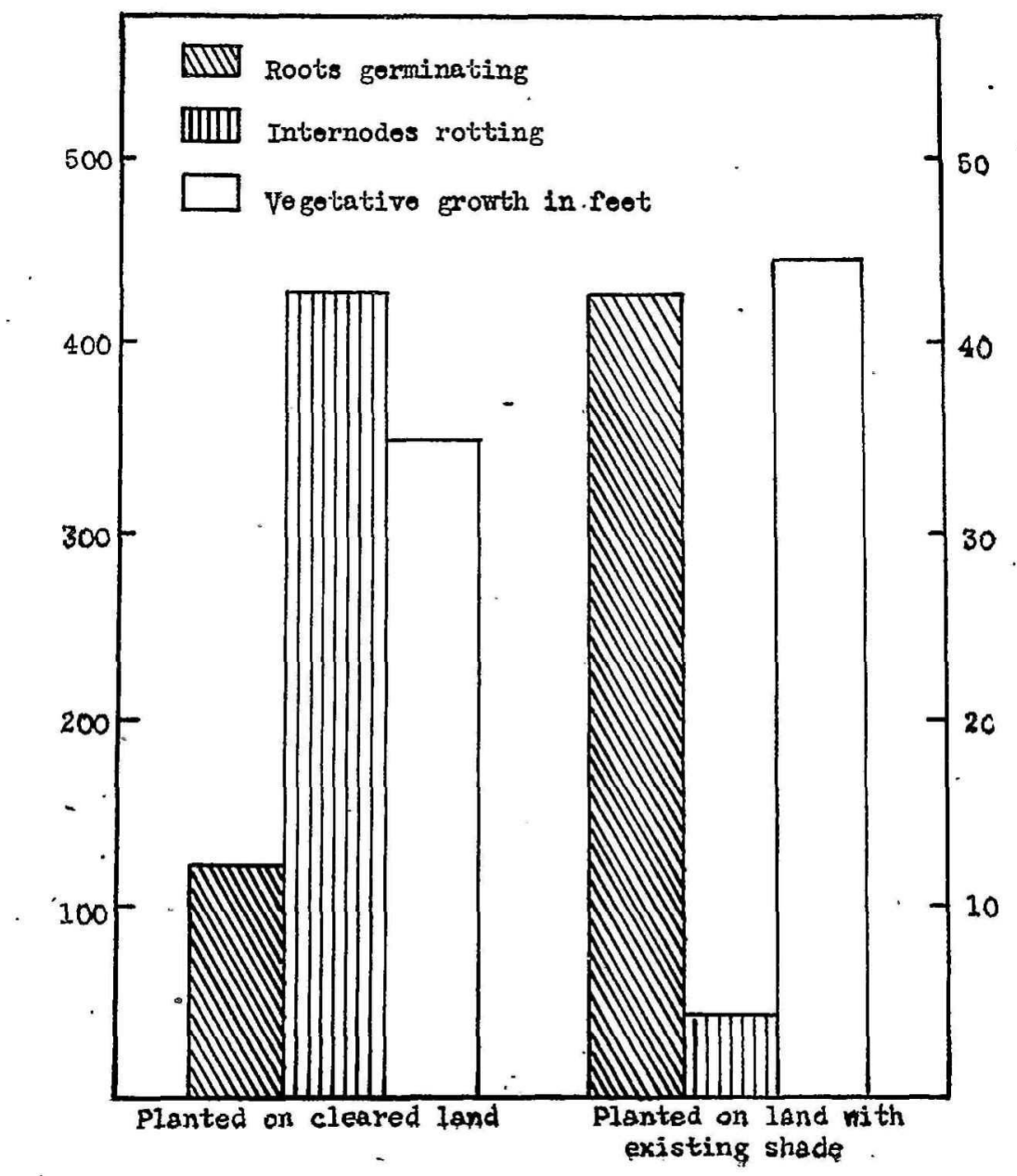

Figure. 1 , 
Character of vine growth under existing shade was distinct from that on cleared land.

From the beginning of the experiment it was observed that the internodes of the vines under existing shade were rather thin and long, as illustrated in figure 2 , as compared to the short and thick internodes of the vines on cleared land, as shown in figure 3. The color of the former was dark green, characteristic of healthy normal plants, while that of the latter was an unhealthy yellow. This undesirable color of the vines on cleared land was doubtless due to excessive exposure to the sun's rays, intensified by the bucare supports shedding their leaves during the dry season.

This, experiment clearly supports other observations that vanilla vines can be planted to advantage on.land with existing shade with only a minimum amount of clearing. Furthermore, the planting can take place immediately after land preparation, eliminating a delay of from 1 to 2 years until the support trees have developed sufficient shade to protect the plants. Although bucare was used as a support in this experiment, it is now known that vanilla vines can be planted on available existing shade trees most of which serve the same purpose with equal satisfaction. 


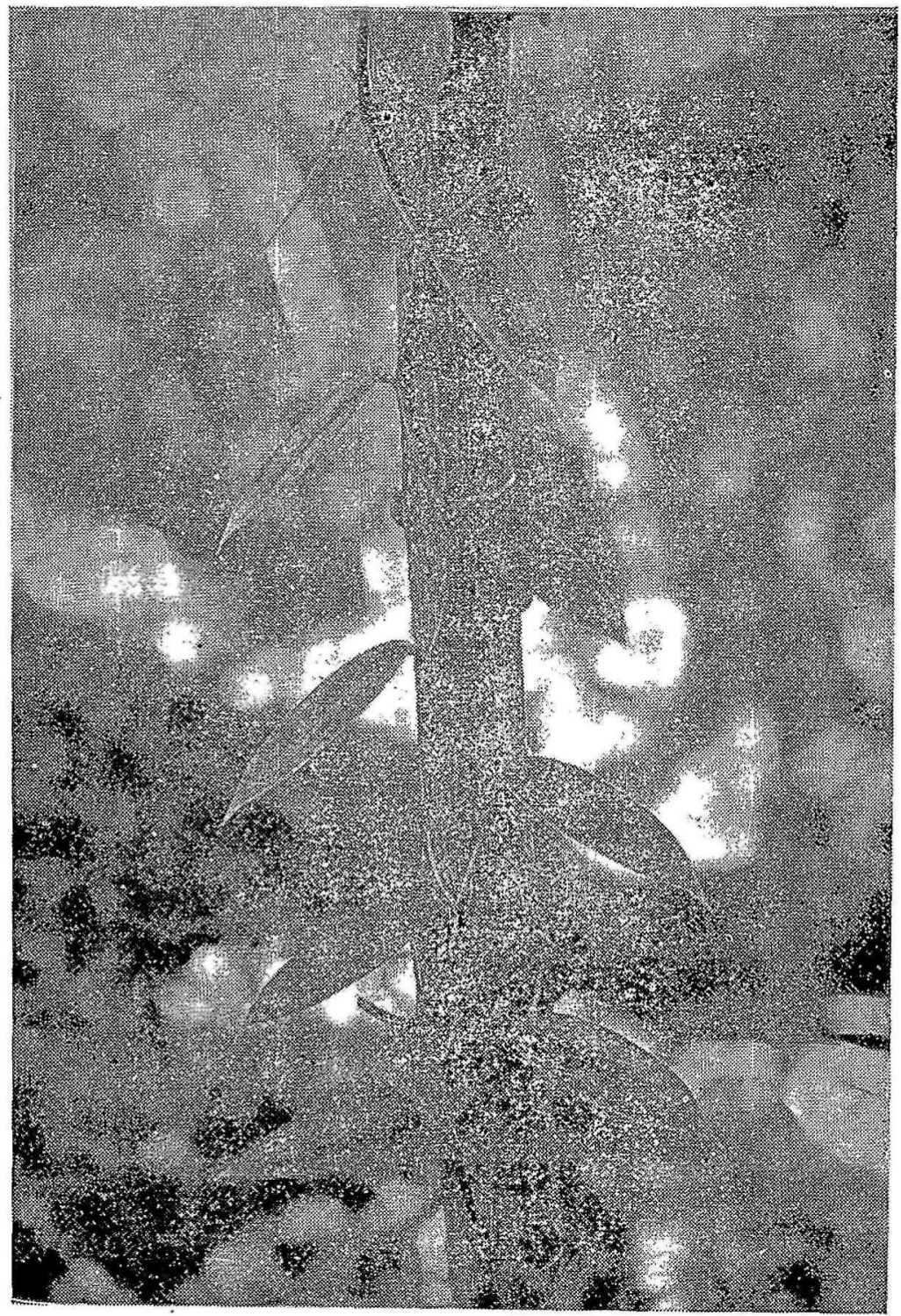

Figure 2. Character of vine growth of Vanilla fragrans, vine planted on underbrushed land. Note the long, thin internodes. The leaves were long, narrow, and of a healthy dark-green color, 


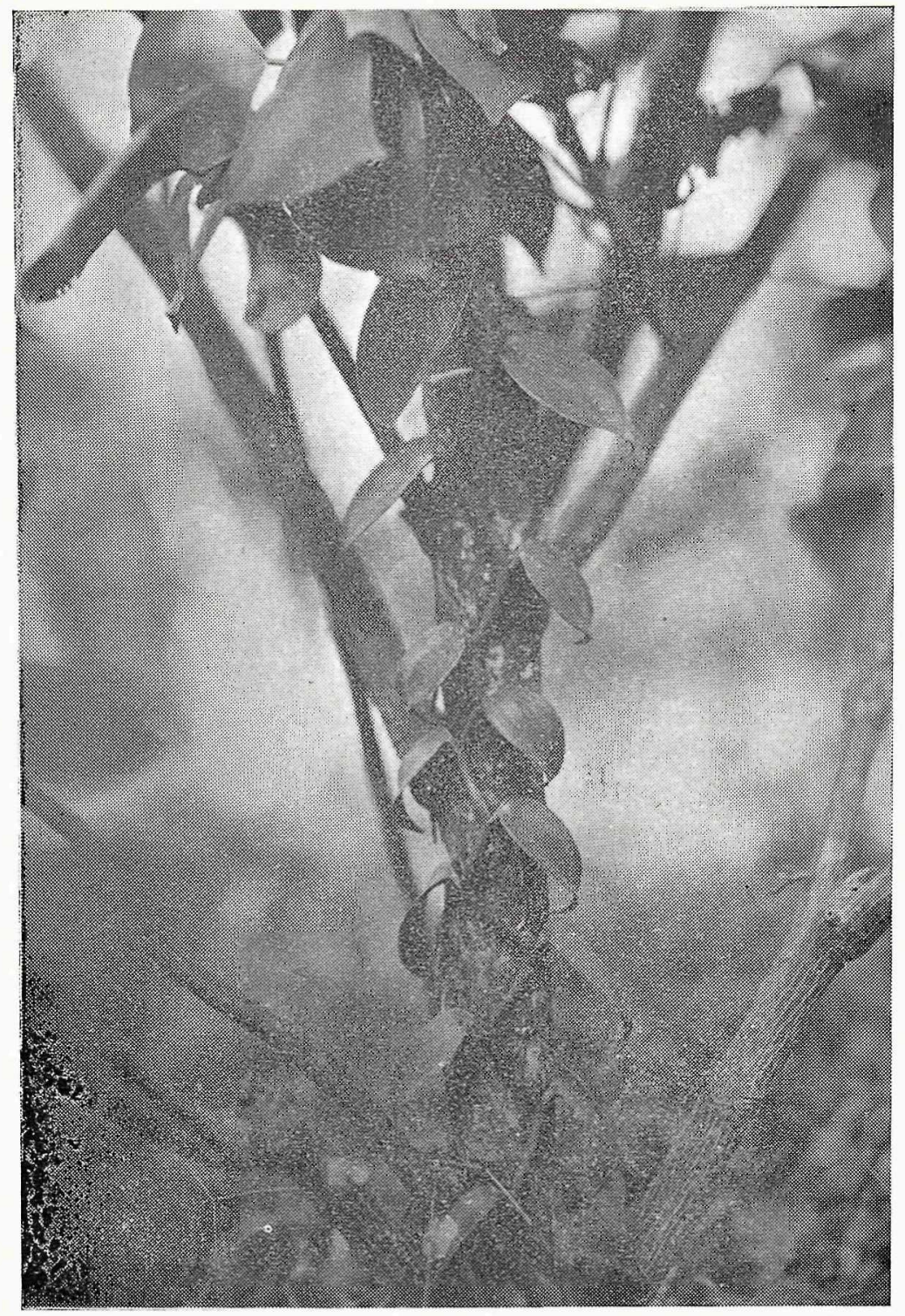

Figure 3. Character of growth of Vanilla fragrans planted on cleared land. Note the short, thick internodes. The leaves were short, thick, wide, cupped, and rather yellow due to excessive exposure to sun rays, intensified by the leaf shedding of the bucare supports during the dry season. 
When vanilla was grown on bucare supports under existing shade it produced more root germination, less seed-piece rotting, and more regetative growth than when grown on the same kind of support trees on cleared land. The differences between the two groups of vines were considerable. The vines under existing shade were of a dark-green color characteristic of healthy normal plants as compared to the yellowish color of the vines grown on cleared land. Because of the nature of dwarf bucare to shed its leaves during the dry season, at the time when the vanilla plant needs shade, it would be preferable to use this support, where needed, only under natural or existing shade.

\section{Acknowledgement}

The writer wishes to express his appreciation of valuable suggestions during the procedure of the experiment received from Dr. Arthur G. Kevorkian, former assistant plant pathologist and physiologist in charge of vanilla investigations. 